\title{
INFORMAL TAXATION IN SIERRA LEONE: \\ MAGNITUDES, PERCEPTIONS AND IMPLICATIONS
}

VANESSA VAN DEN BOOGAARD
UNIVERSITY OF TORONTO 


\section{Outline}

$\square$ Introduction: Tax, development, and informality

$\square$ Case study: Informal fiscal reality in Sierra Leone

$\square$ Implications and ways forward 


\section{INTRODUCTION}




\section{Taxation and state-building}

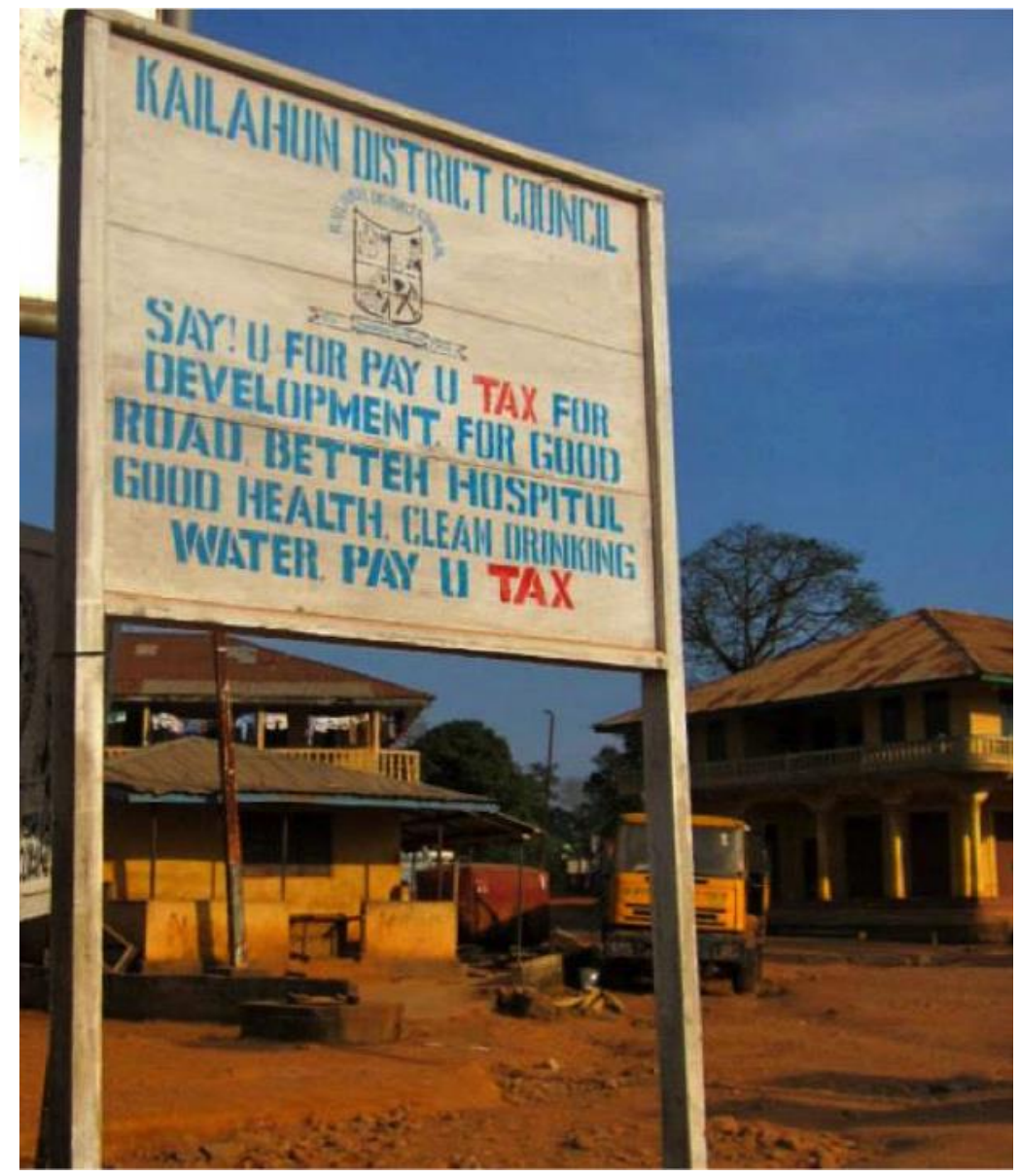




\section{Taxation and state-building}

$\square$ Sustainable development

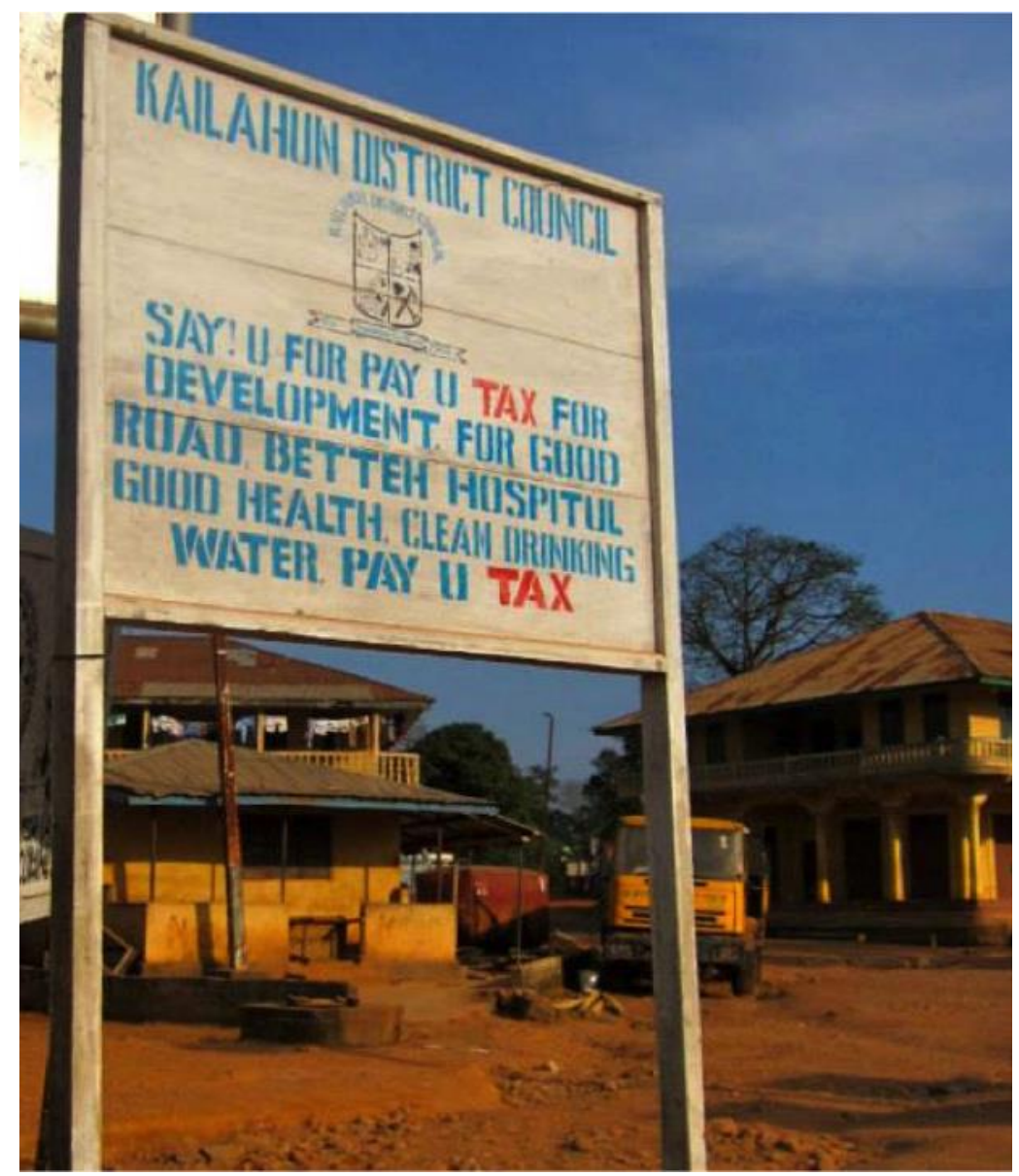




\section{Taxation and state-building}

$\square$ Sustainable development

$\square$ State capacity

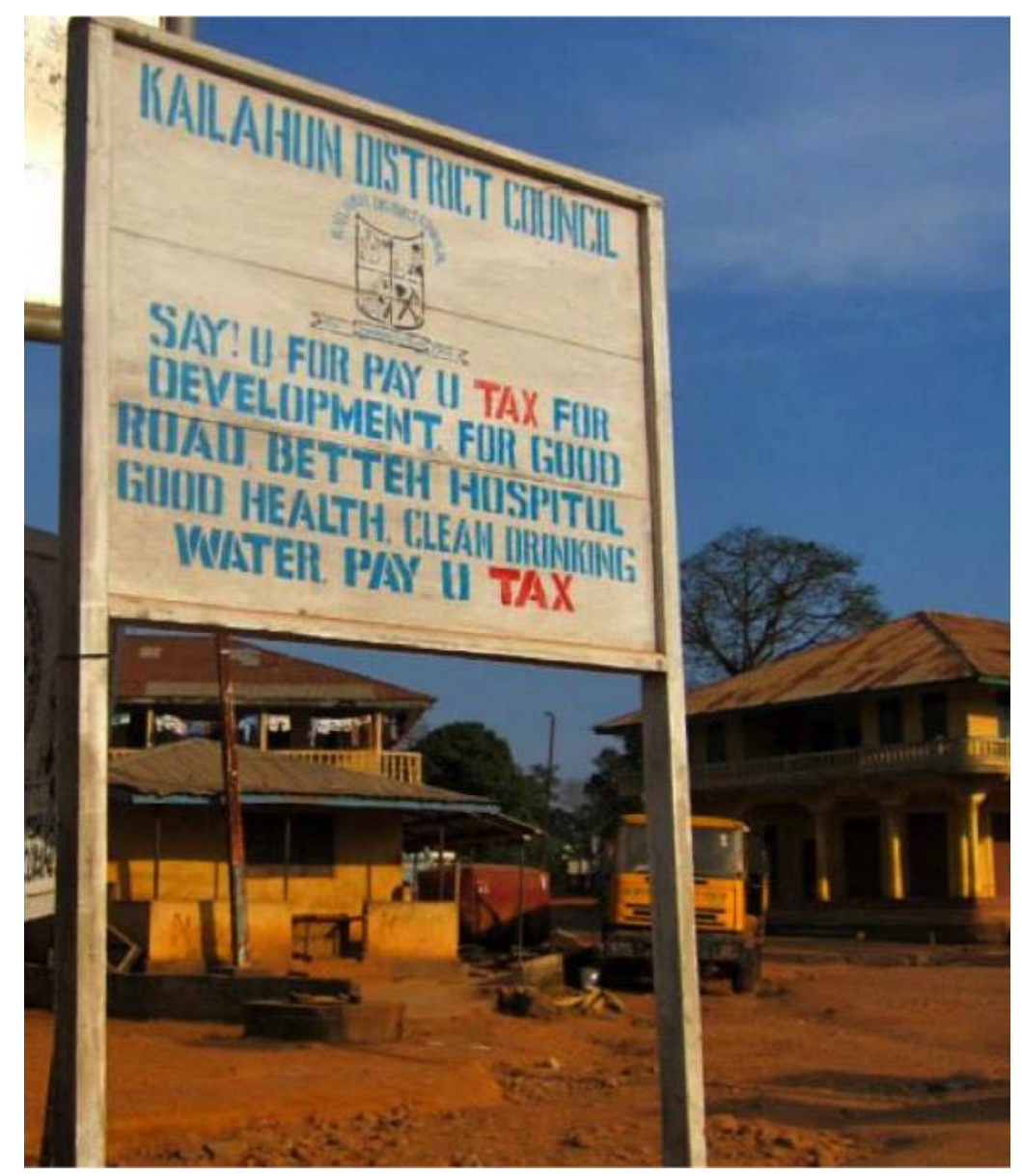




\section{Taxation and state-building}

$\square$ Sustainable development

$\square$ State capacity

$\square$ State-society accountability processes

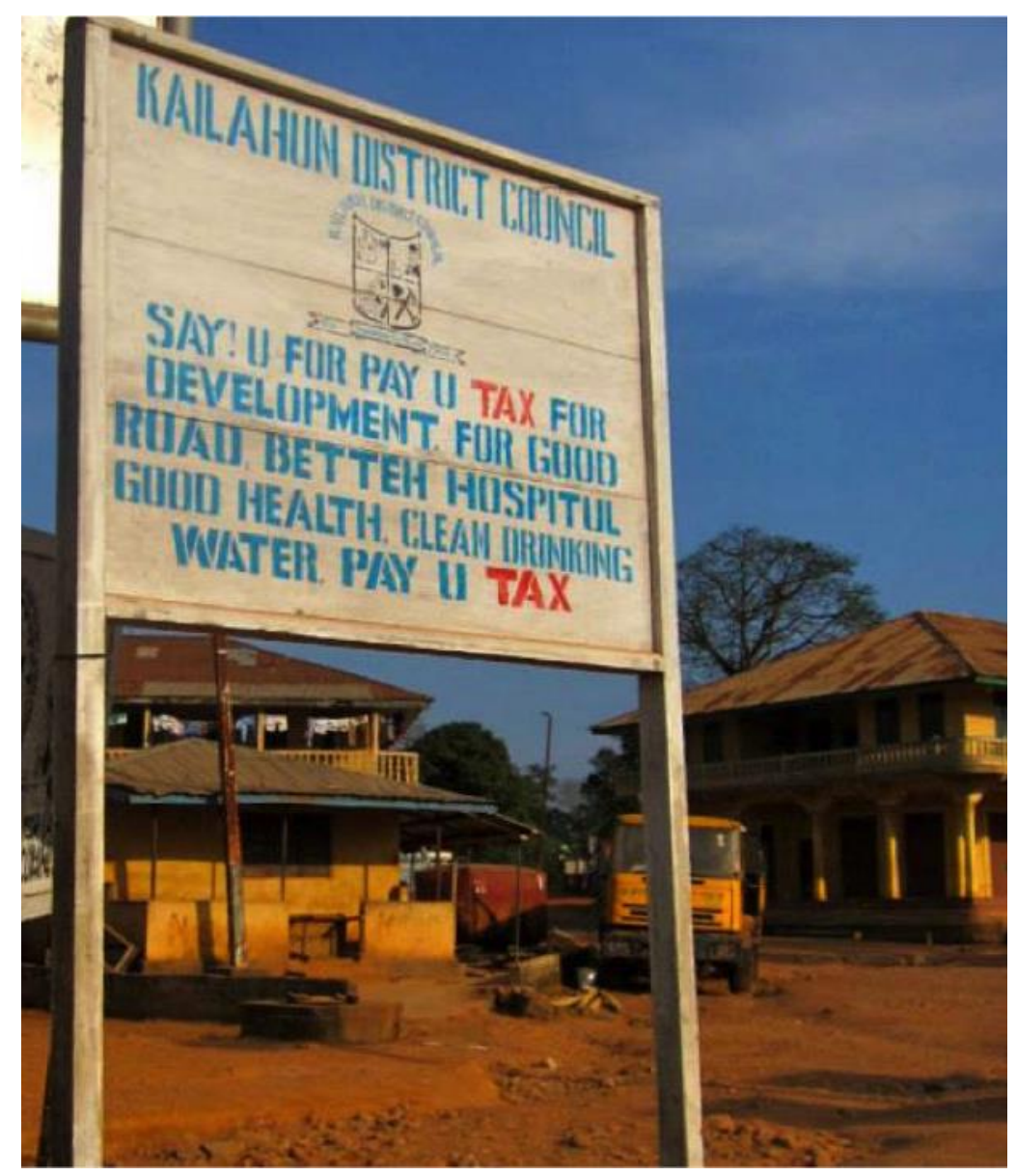




\section{Theory vs. practice}

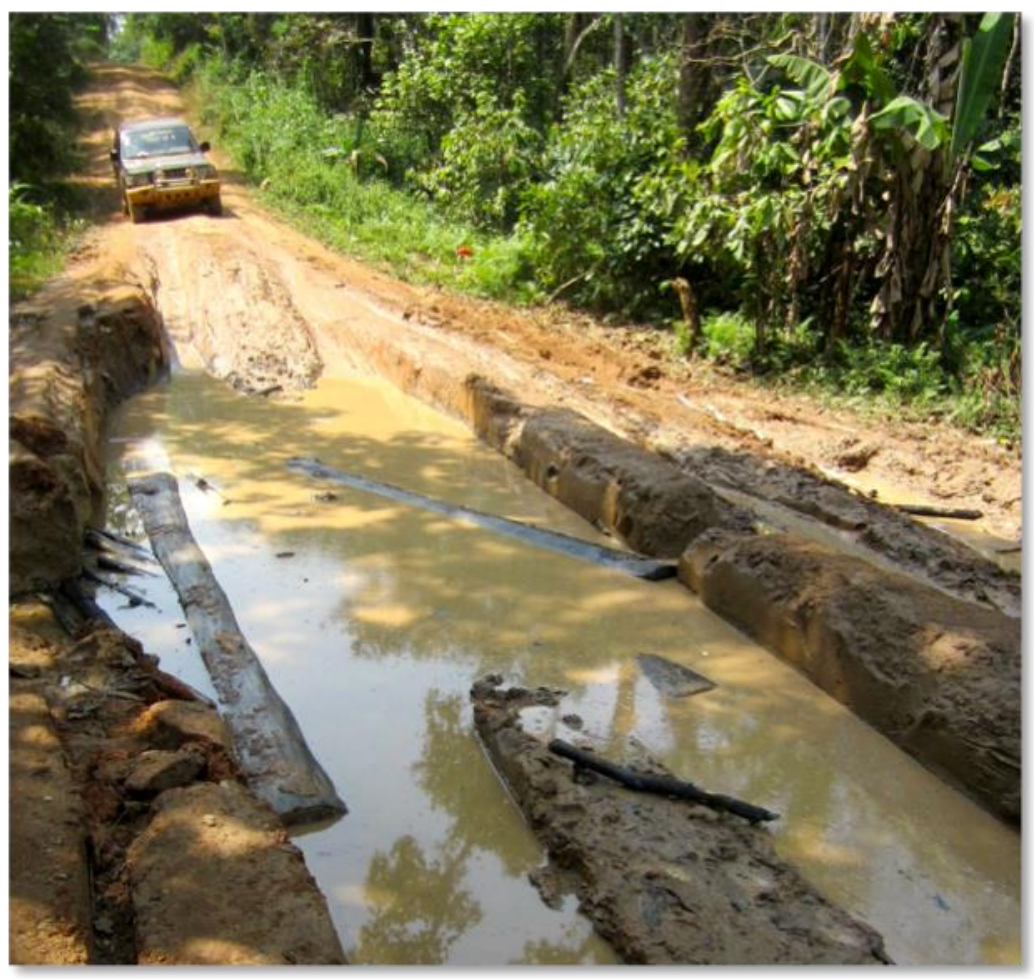




\section{Theory vs. practice}

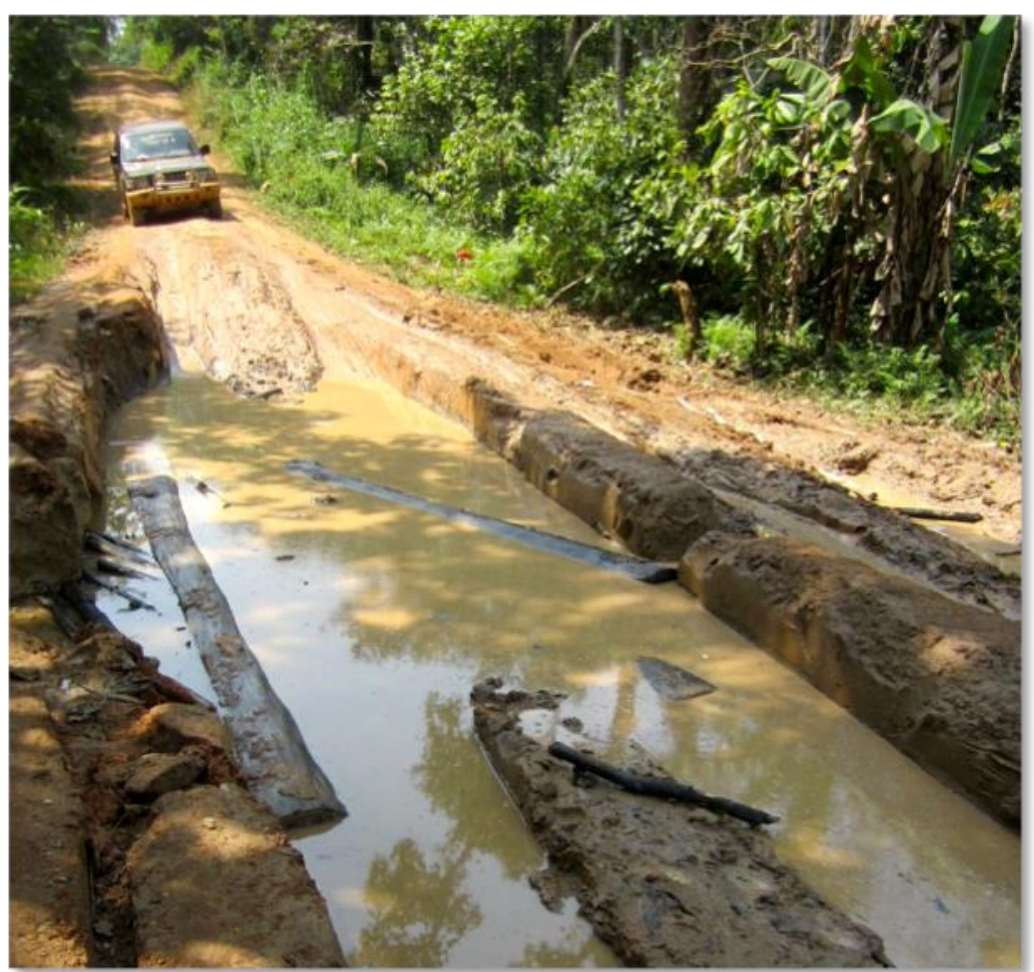

$\square$ Limited capacity and poor incentives 


\section{Theory vs. practice}

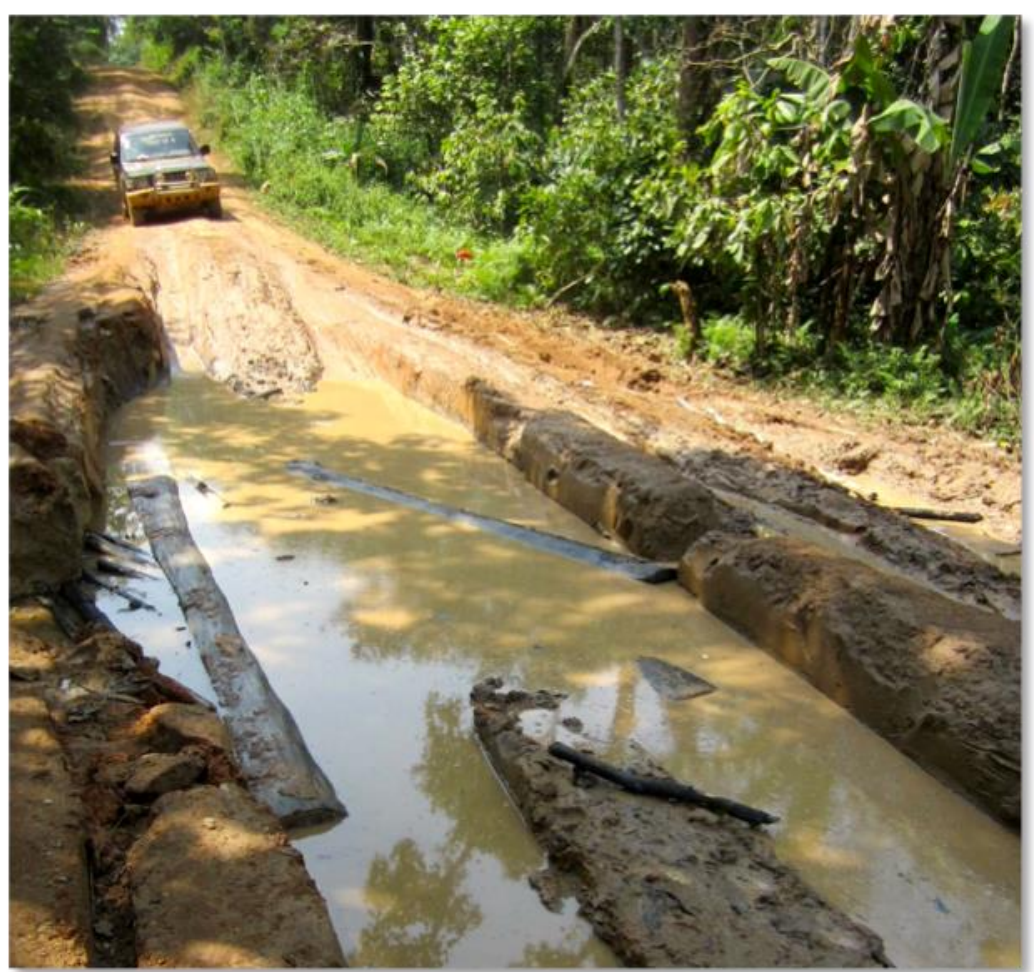

$\square$ Limited capacity and poor incentives

$\square$ Predatory taxation 


\section{Theory vs. practice}

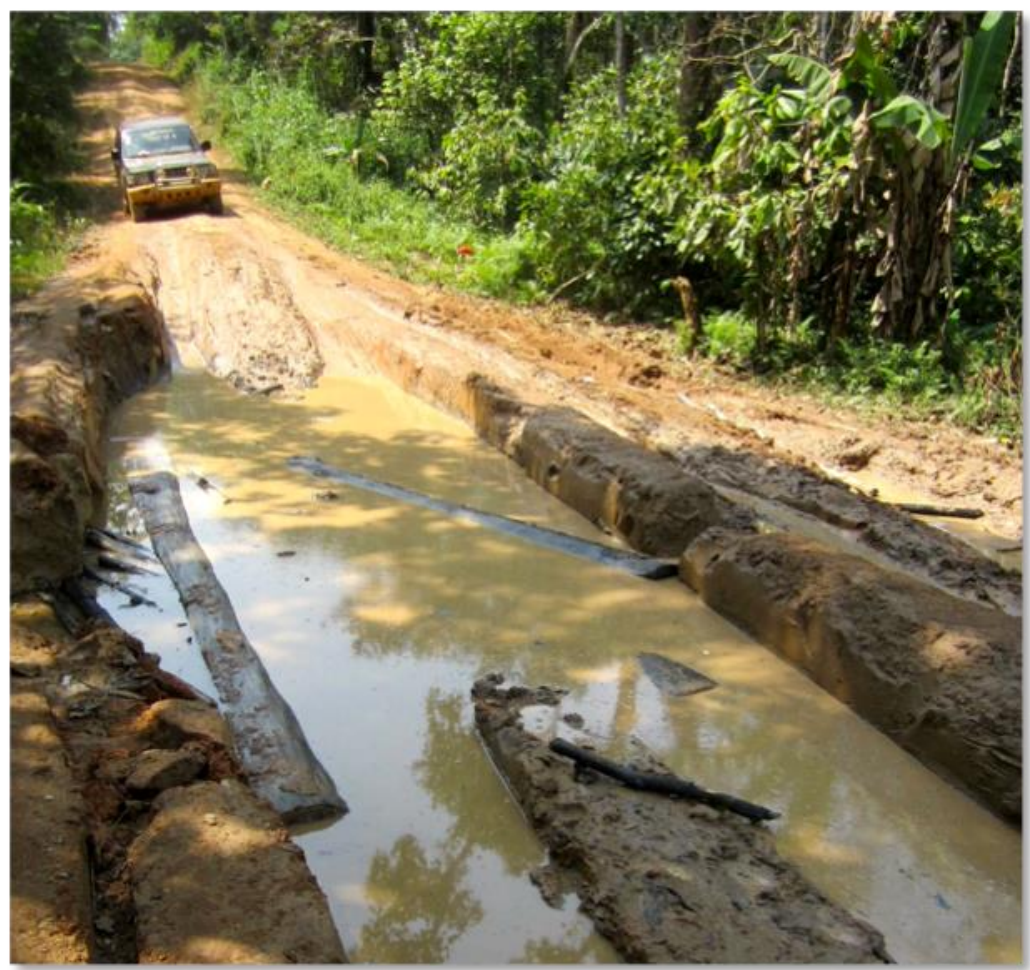

$\square$ Limited capacity and poor incentives

$\square$ Predatory taxation

$\square$ Obstacles to collective action 


\section{Theory vs. practice}

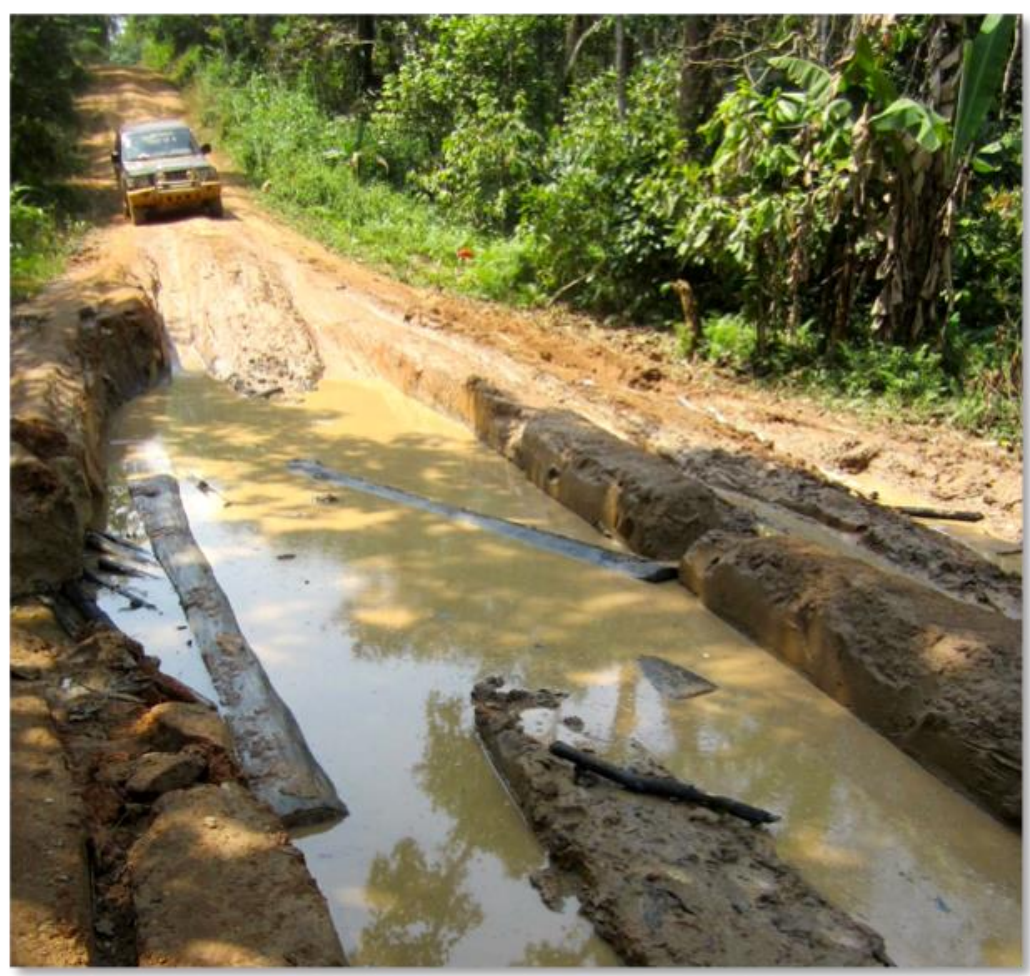

$\square$ Limited capacity and poor incentives

$\square$ Predatory taxation

$\square$ Obstacles to collective action

$\square$ Focus on formal tax systems 


\section{Informal Fiscal Realities}

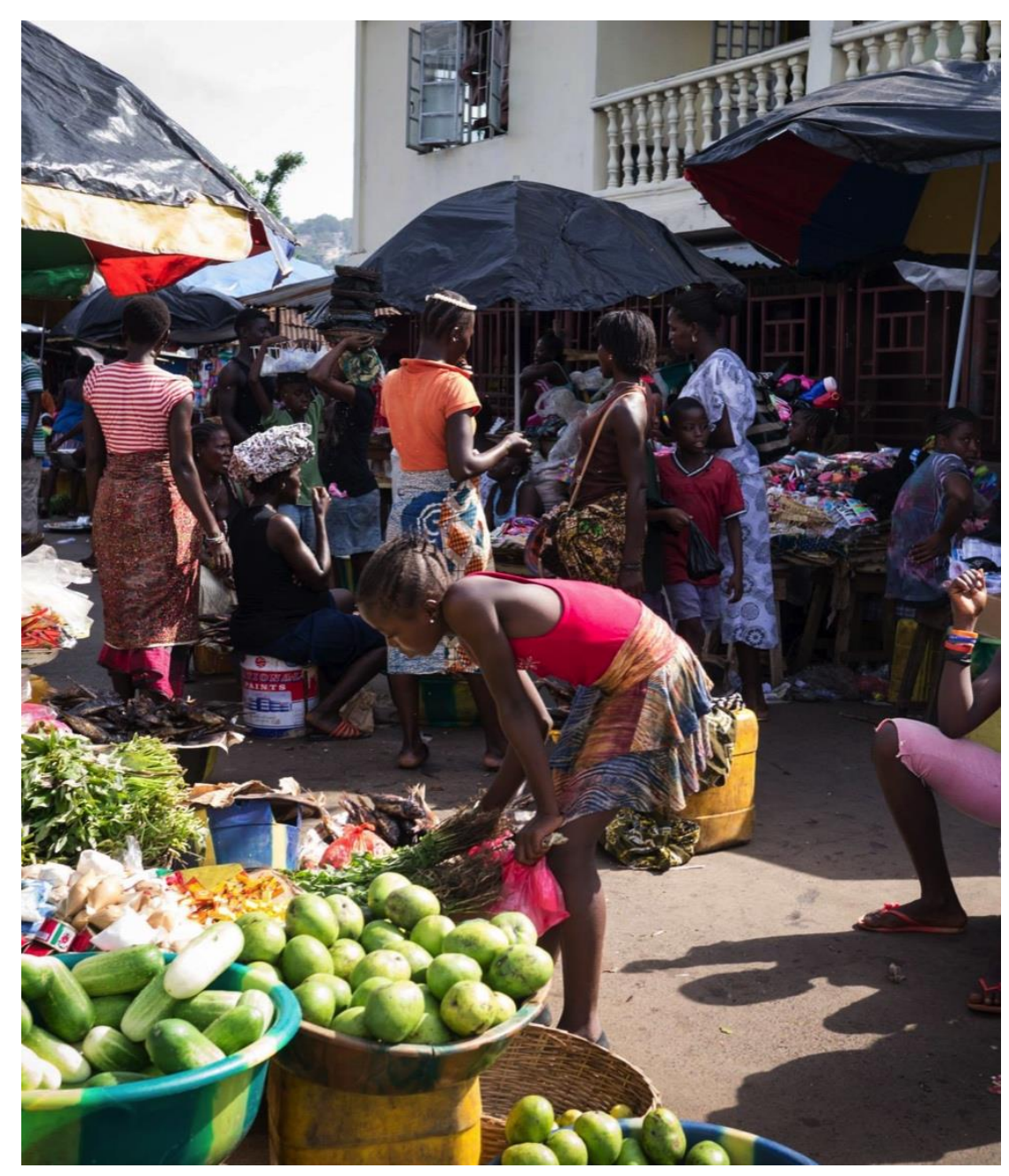




\section{Informal Fiscal Realities}

$\square$ Informal tax

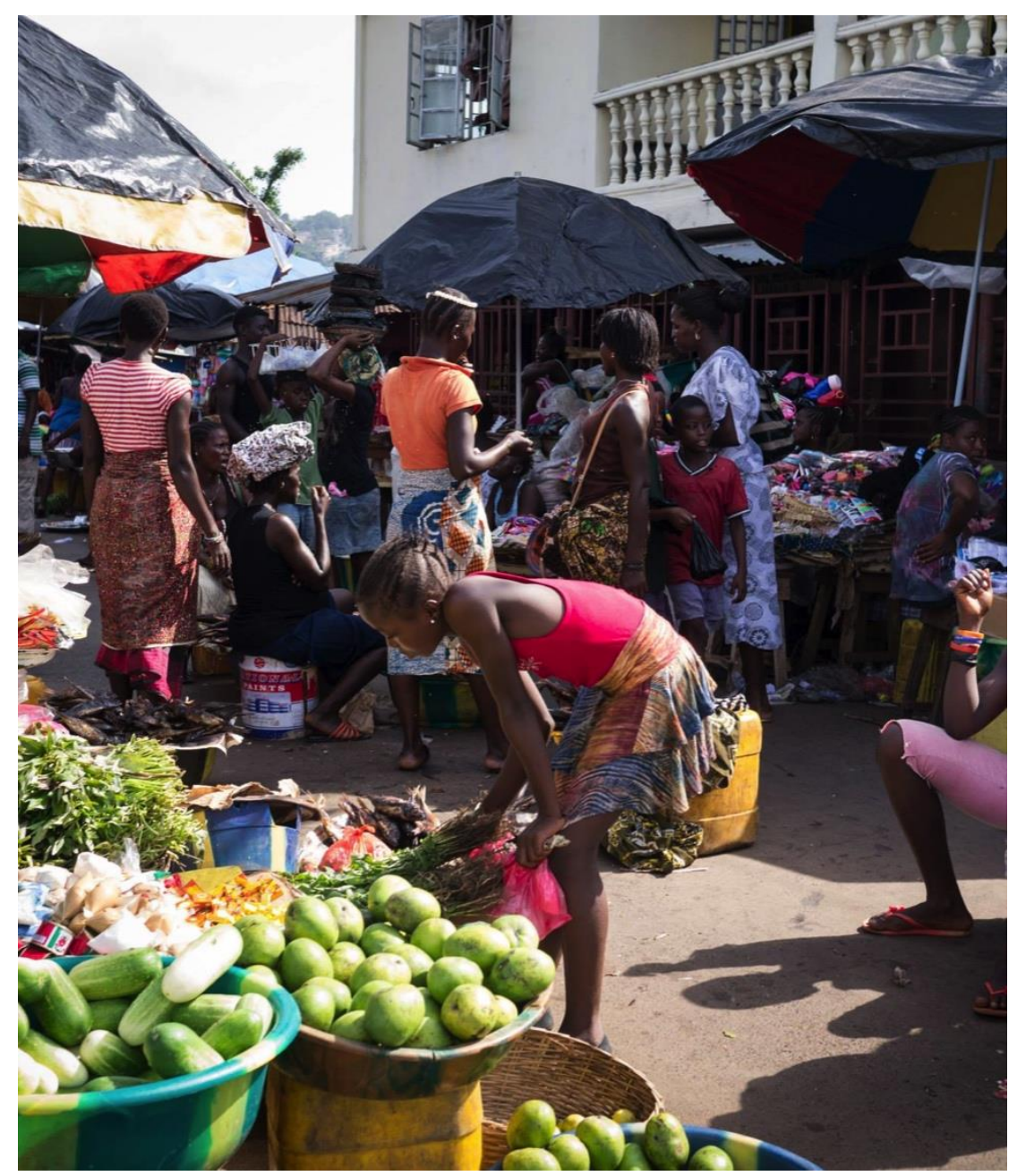




\section{Informal Fiscal Realities}

$\square$ Informal tax

口 Contributions from individuals, households and businesses

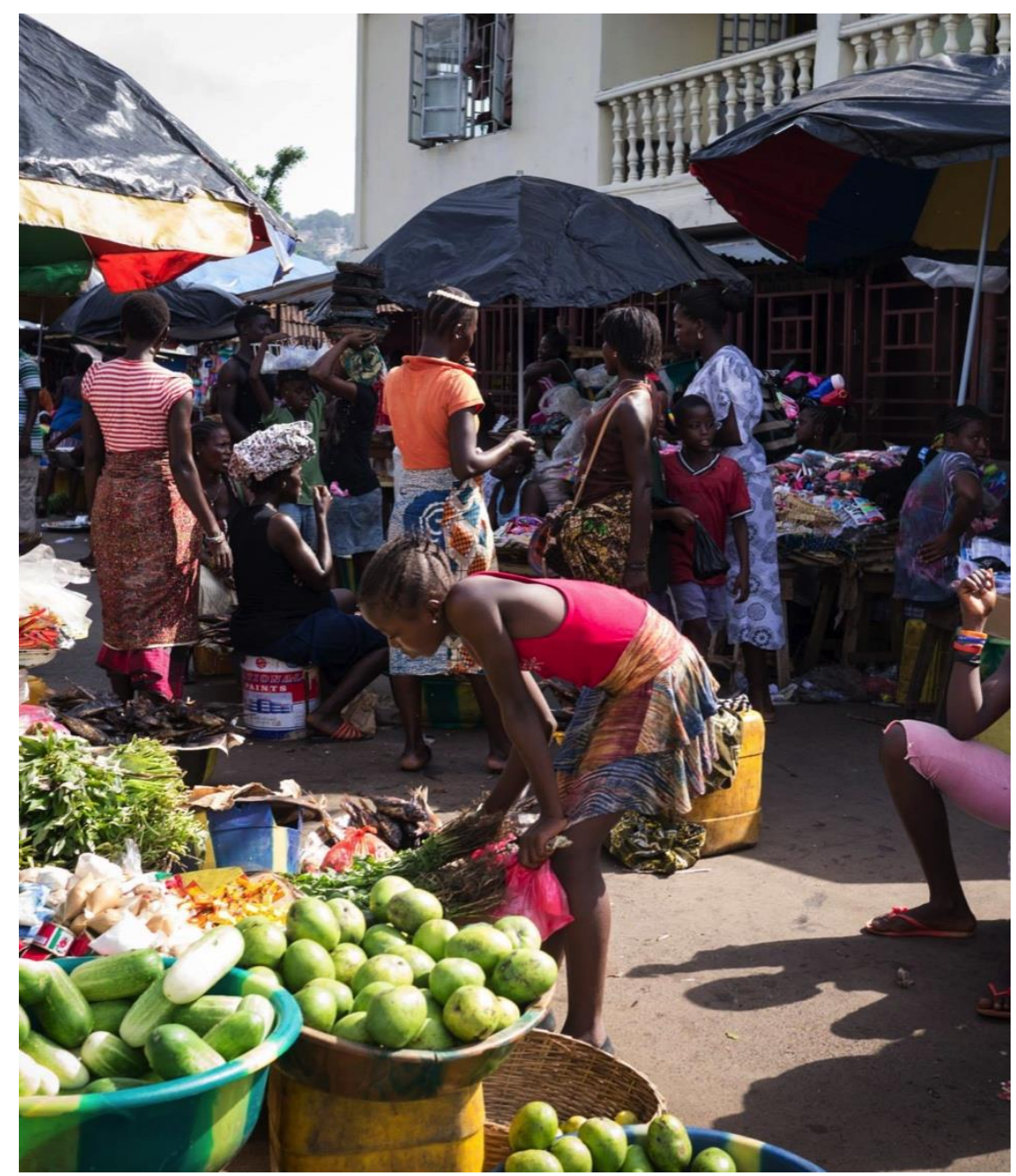




\section{Informal Fiscal Realities}

$\square$ Informal tax

口 Contributions from individuals, households and businesses

- Enforced through means outside of the formal legal system

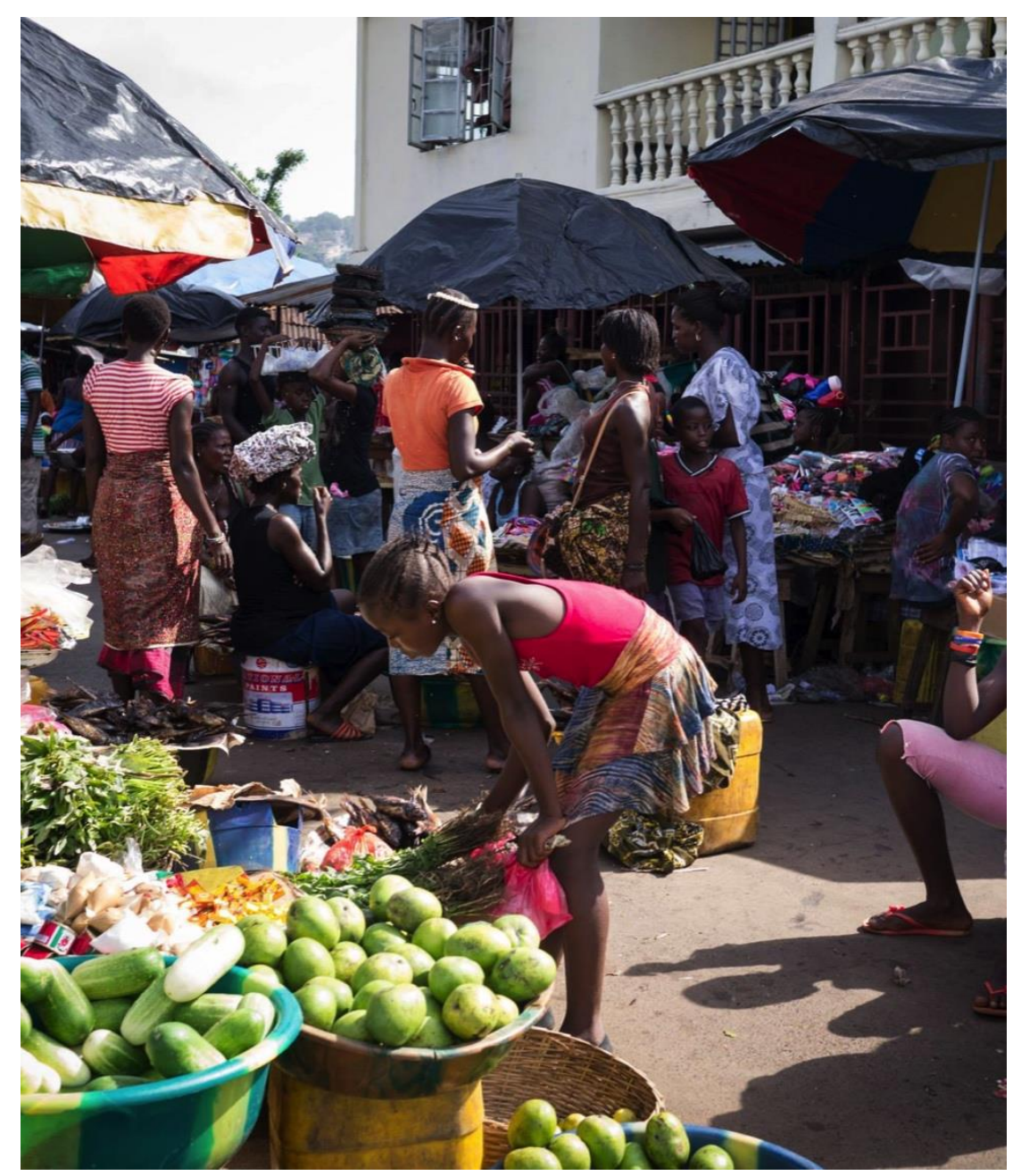




\section{Informal Fiscal Realities}

$\square$ Informal tax

口 Contributions from individuals, households and businesses

- Enforced through means outside of the formal legal system

- May finance local public goods in the absence of strong state institutions

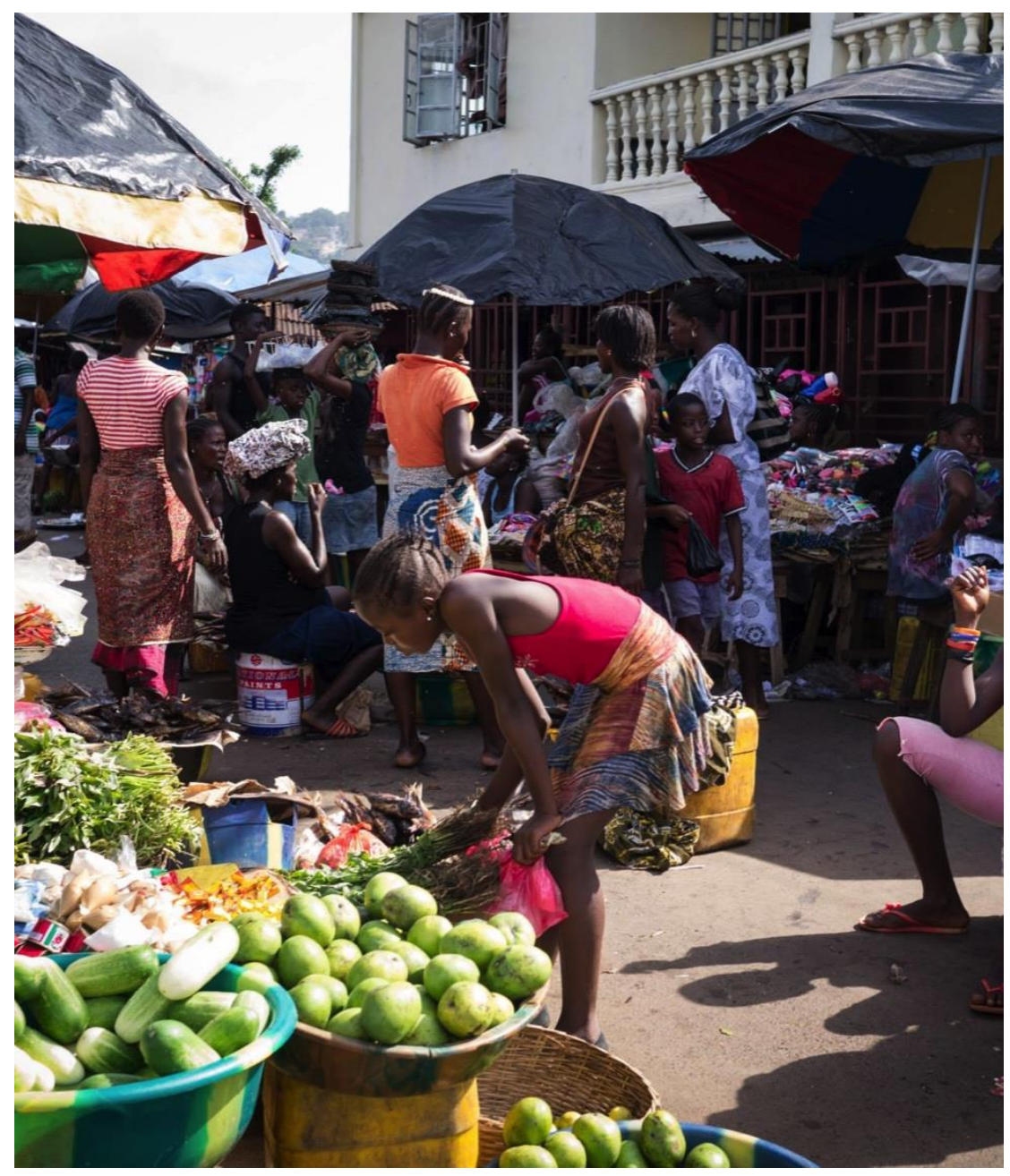




\section{Informal Fiscal Realities}

$\square$ Informal tax

口 Contributions from individuals, households and businesses

- Enforced through means outside of the formal legal system

- May finance local public goods in the absence of strong state institutions

$\square$ Importance of user fees

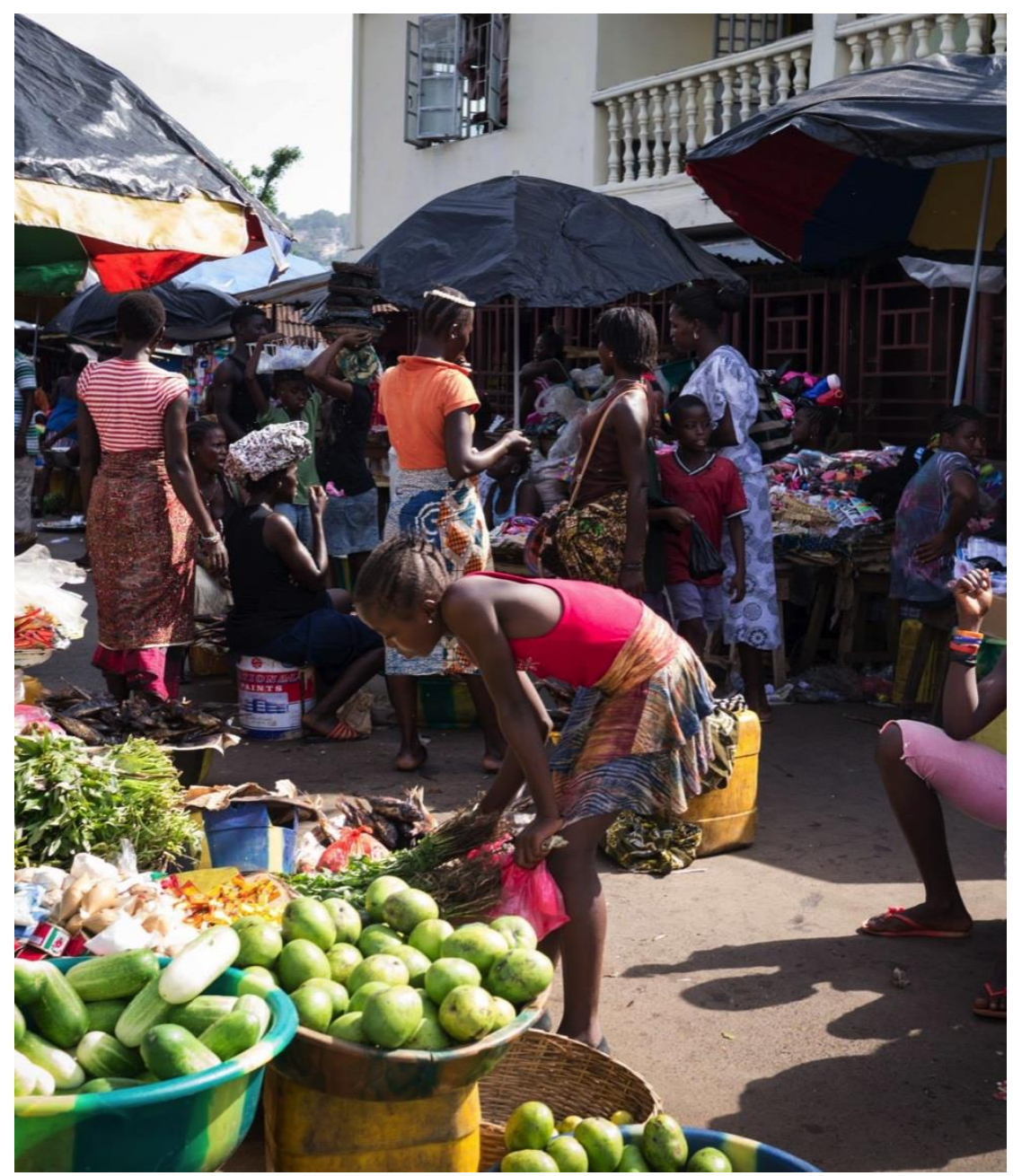


Why does this matter? 


\section{Why does this matter?}

$\square$ Underestimation of tax burdens 


\section{Why does this matter?}

$\square$ Underestimation of tax burdens

$\square$ Misunderstanding of dynamics of local governance

- and appropriate policy responses 


\section{Why does this matter?}

$\square$ Underestimation of tax burdens

$\square$ Misunderstanding of dynamics of local governance

- and appropriate policy responses

$\square$ Need to rethink the potential of taxation to provide spur for greater accountability or institutional development 


\section{Case study: Sierra Leone}

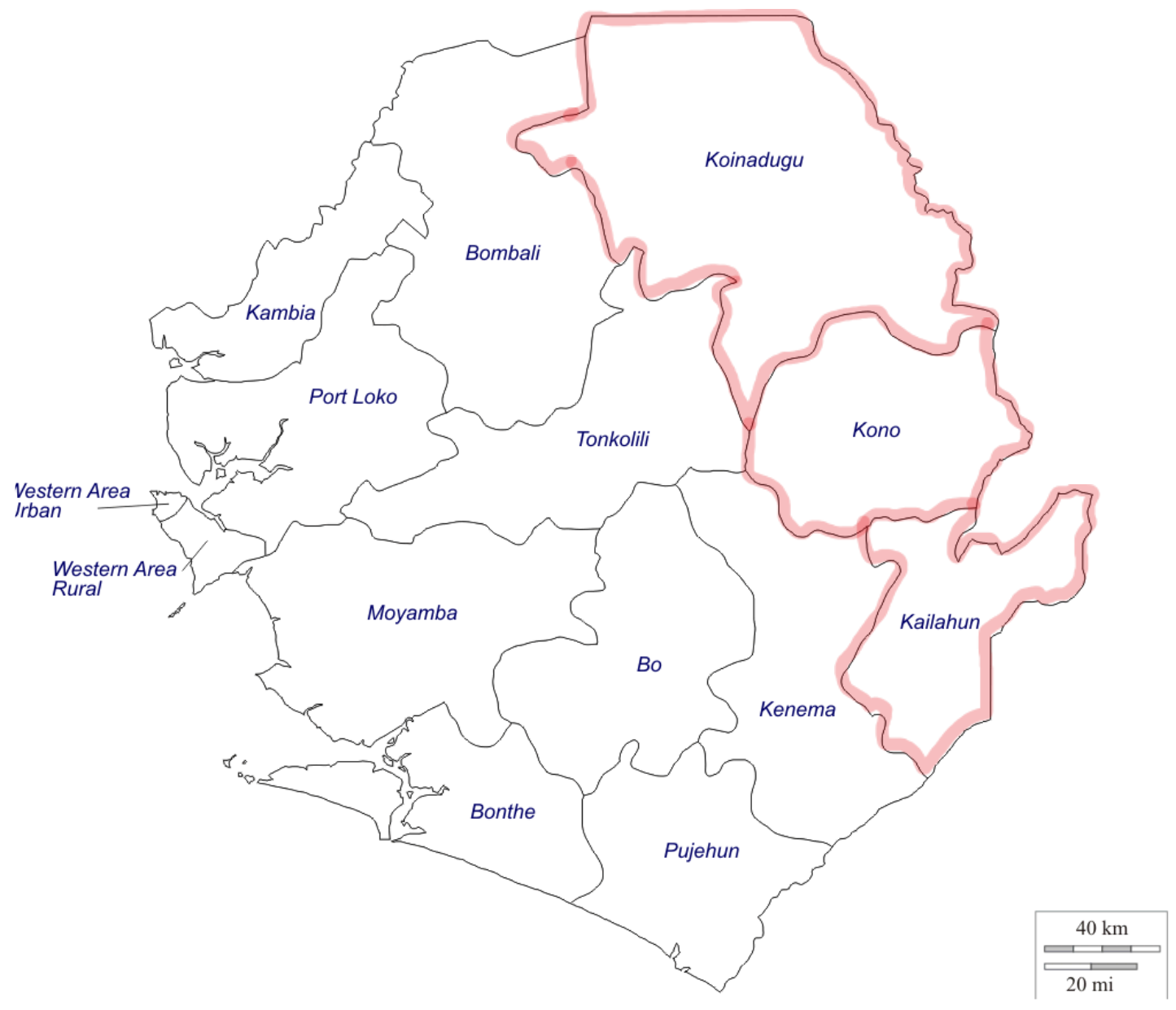




\section{Research Methods}
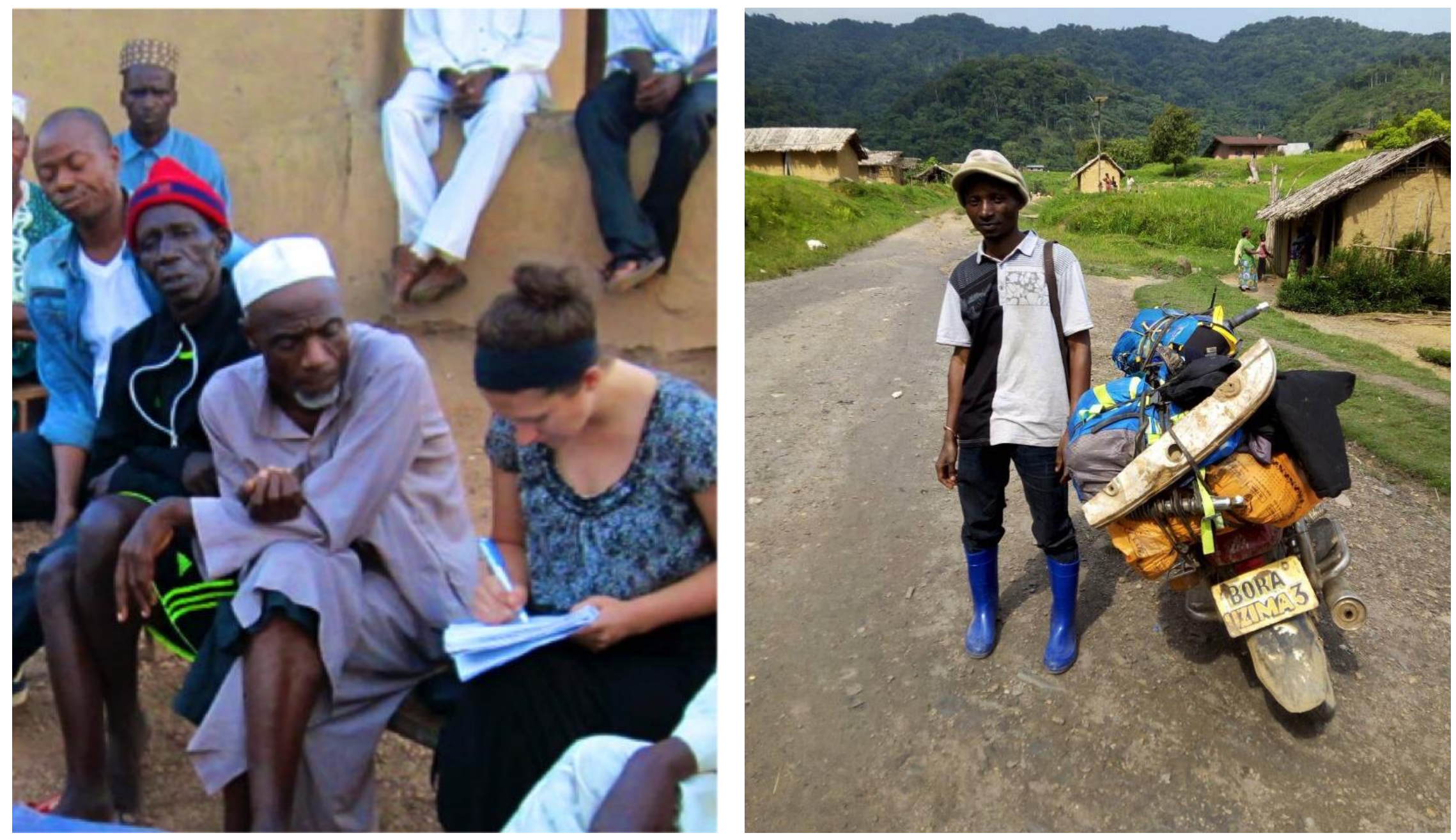
II. INFORMAL FISCAL REALITIES

IN SIERRA LEONE 


\section{Informal Fiscal Realities}

\begin{tabular}{|l|l|l|}
\hline User fees & Definition & School fees \\
\hline $\begin{array}{l}\text { Fees charged directly for } \\
\text { government services }\end{array}$ & Public health fees \\
\hline & & \\
\hline & & \\
\hline & & \\
\hline & & \\
\hline & & \\
\hline
\end{tabular}




\section{Informal Fiscal Realities}

\begin{tabular}{|l|l|l|}
\hline User fees & Definition & Examples \\
\hline $\begin{array}{l}\text { Fees charged directly for } \\
\text { government services }\end{array}$ & School fees \\
\hline $\begin{array}{l}\text { Informal user } \\
\text { fees }\end{array}$ & $\begin{array}{l}\text { Fees charged to finance a local, } \\
\text { non-governmental public good, or to } \\
\text { provide supplemental financing to a } \\
\text { governmental public good }\end{array}$ & $\begin{array}{l}\text { Contributions to support community } \\
\text { teachers }\end{array}$ \\
\hline & \begin{tabular}{l} 
Payments to caretakers of water wells \\
\hline
\end{tabular} & $\begin{array}{l}\text { Payments to service providers (nurses, } \\
\text { police, etc.) }\end{array}$ \\
\hline & & \\
\hline
\end{tabular}




\section{Informal Fiscal Realities}

\begin{tabular}{|c|c|c|}
\hline & Definition & Examples \\
\hline User fees & $\begin{array}{l}\text { Fees charged directly for } \\
\text { government services }\end{array}$ & $\begin{array}{l}\text { School fees } \\
\text { Public health fees }\end{array}$ \\
\hline $\begin{array}{l}\text { Informal user } \\
\text { fees }\end{array}$ & $\begin{array}{l}\text { Fees charged to finance a local, } \\
\text { non-governmental public good, or to } \\
\text { provide supplemental financing to a } \\
\text { governmental public good }\end{array}$ & $\begin{array}{l}\text { Contributions to support community } \\
\text { teachers } \\
\text { Payments to caretakers of water wells } \\
\text { Payments to service providers (nurses, } \\
\text { police, etc.) }\end{array}$ \\
\hline Informal taxes & $\begin{array}{l}\text { Contributions collected by non-state } \\
\text { actors to finance local public goods } \\
\text { or support non-state institutions }\end{array}$ & $\begin{array}{l}\text { Contributions for community } \\
\text { development projects, community } \\
\text { security, hosting guests }\end{array}$ \\
\hline
\end{tabular}




\section{Magnitude of informal tax}

Mean proportion of expenditures on tax per annum, average for tax type

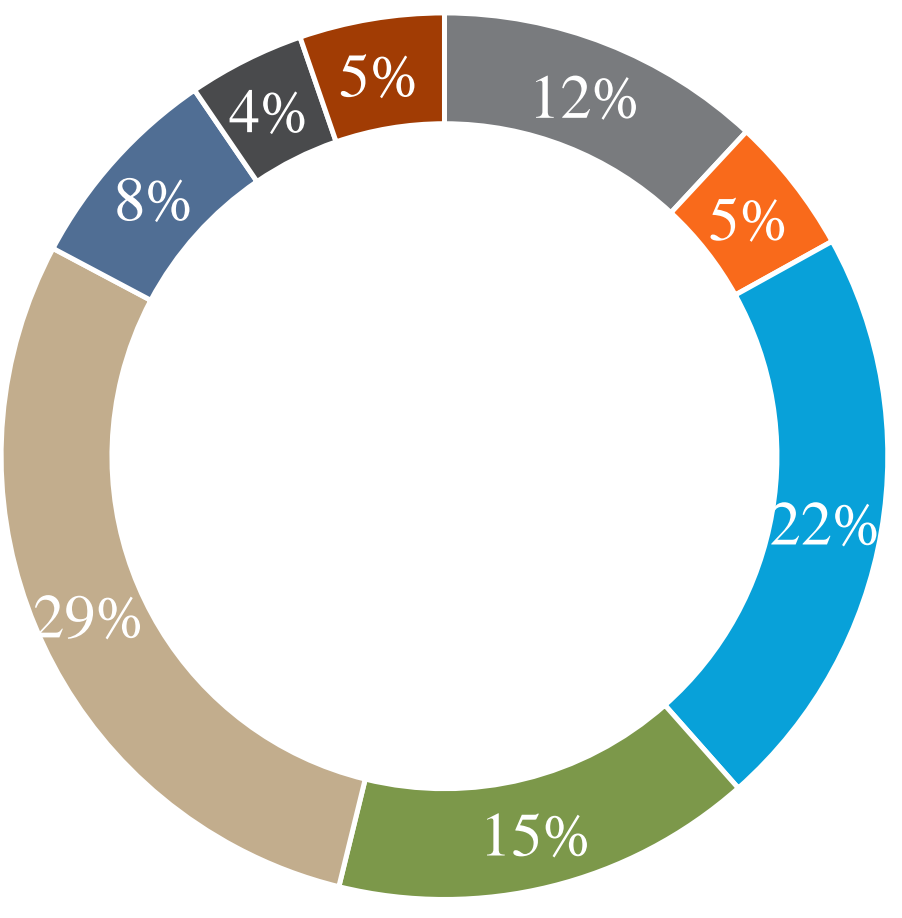

- Central government taxes

- Local government taxes

- Formal chiefdom taxes

- Informal chiefdom taxes

User fees

- Informal user fees

- Informal taxes to non-state actors

- Illegal state levies 


\section{Distribution of informal tax}

Mean tax expenditure as a proportion of income, average for tax type

- Lowest quintile $\quad$ Highest quintile

$10 \%$

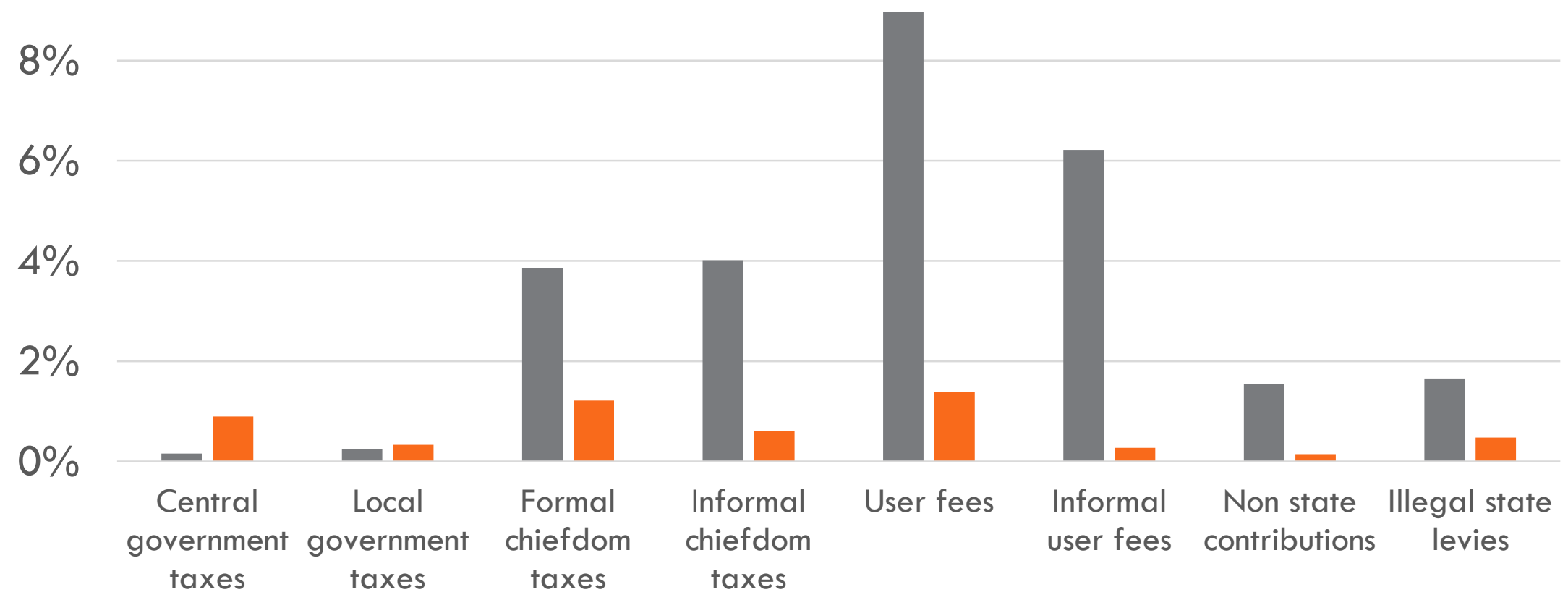




\section{Utility of informal tax}

Percent of respondents reporting the primary good or service they get in return for paying the tax, average for tax type

Nothing

- Specific good/service

Social value

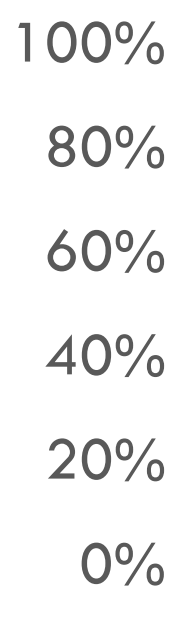

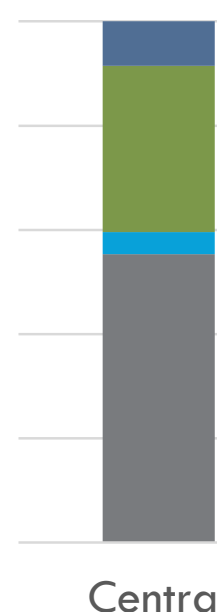

government taxes

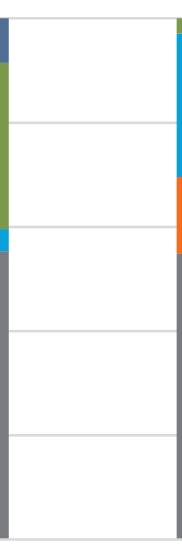

$$
\text { Local }
$$

government taxes
- Avoidance of harassment

- General governing activities

- Don't know

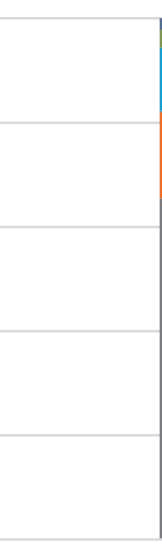

Formal chiefdom taxes

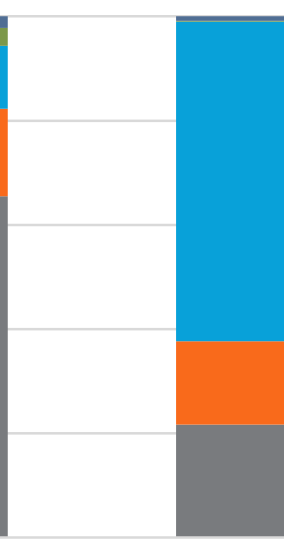

Informal chiefdom taxes
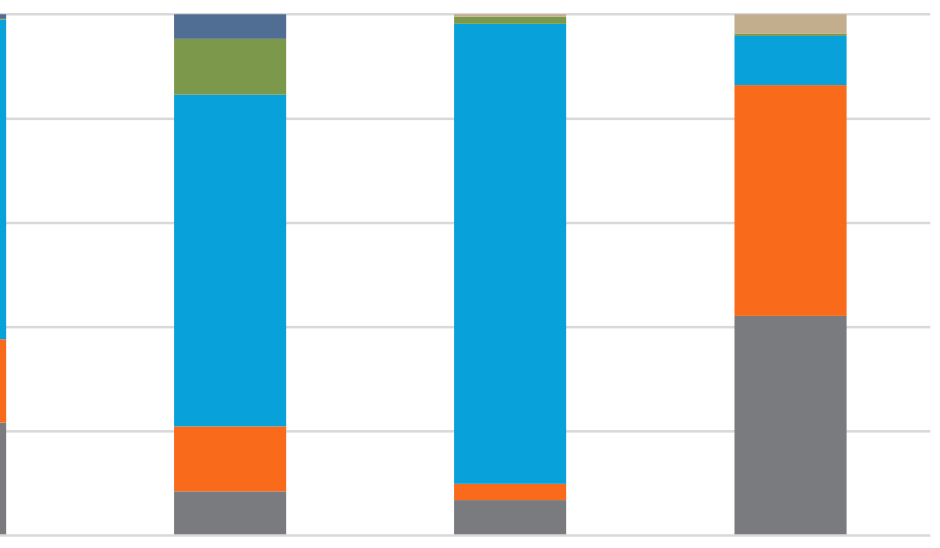

Informal user

Non-state Informal state fees contributions levies 


\section{Accountability of informal tax}

Percent of respondents believing that the actor uses tax revenues to benefit the community some, most, or none of the time, average for tax type

$\square$ None of the time $\square$ Some of the time Most of the time Don't know

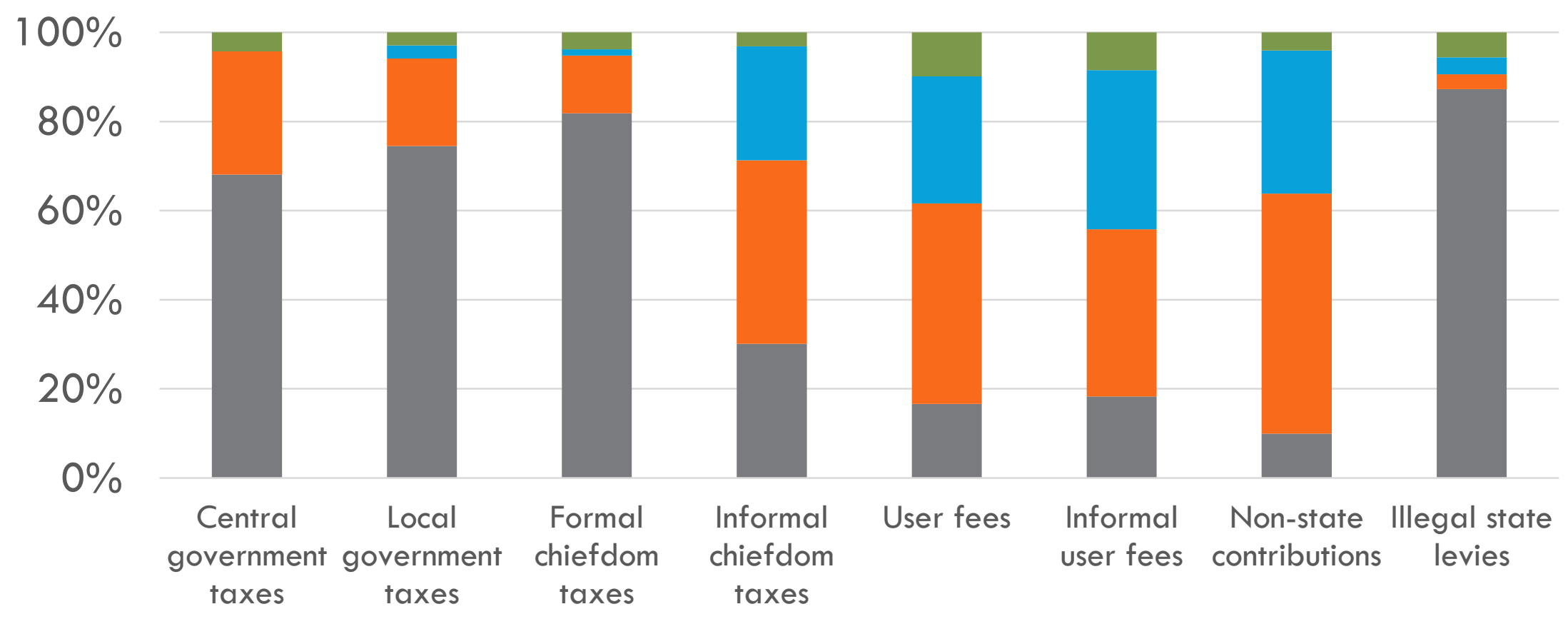


III. IMPLICATIONS AND WAYS FORWARD 


\section{Implications}

"[Informal tax] is normal... it helps communities to be selfreliant... because it takes development where government cannot reach." 


\section{Implications}

$\square$ Recognize that the informal is critical to the reform of the formal

"[Informal tax] is normal... it helps communities to be selfreliant... because it takes development where government cannot reach." 


\section{Implications}

$\square$ Recognize that the informal is critical to the reform of the formal

"[Informal tax] is normal... it helps communities to be selfreliant...because it takes development where government cannot reach." rather than introducing new ones 


\section{Implications}

$\square$ Recognize that the informal is critical to the reform of the formal

$\square$ Look at existing forms of revenue raising, rather than introducing new ones

"[Informal tax] is normal... it helps communities to be selfreliant...because it takes development where government cannot reach."

$\square$ Consider "hybrid" options 


\section{Formal-Informal Partnerships}

"Our role now as councils is to give oversight and a supervisory role over these [informal] facilities and structures set up in the form of committees... the lines

between formal and informal taxes are getting thinner [within communities]."

Chief Administrator, Koinadugu District Council, Sierra Leone 
Risks and remaining questions

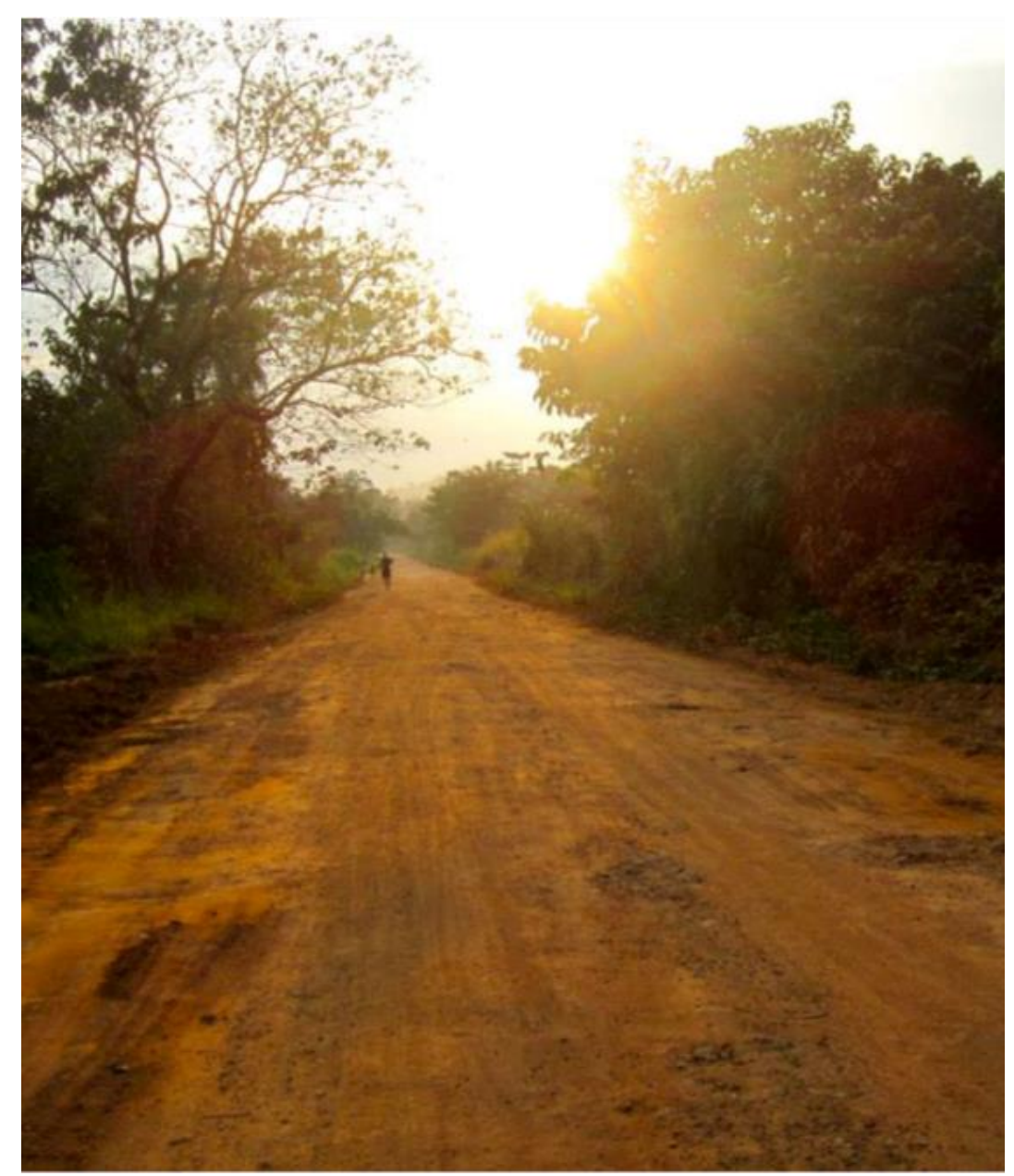




\section{Risks and remaining questions}

Accountability and transparency

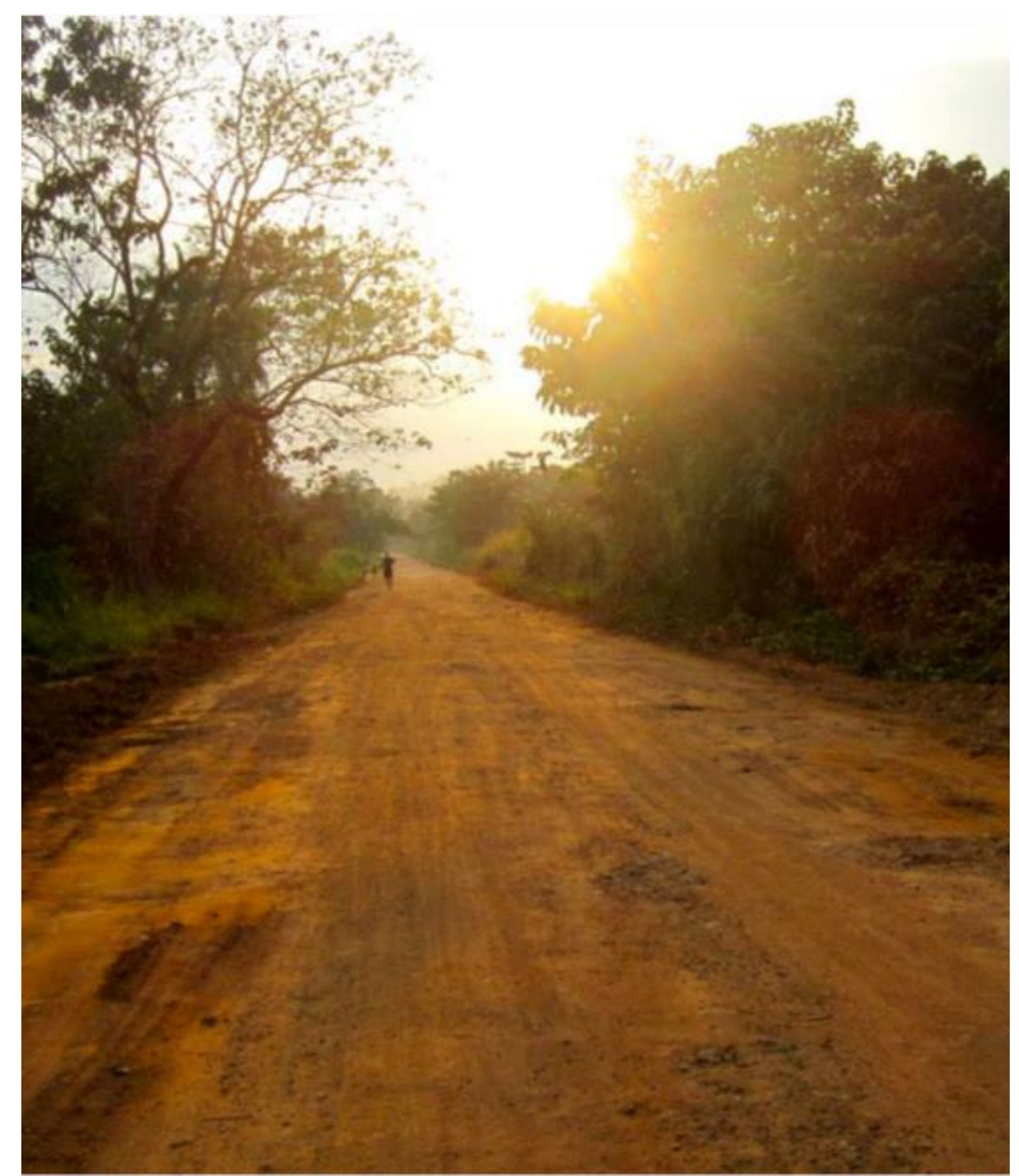




\section{Risks and remaining questions}

$\square$ Accountability and transparency

$\square$ Effectiveness

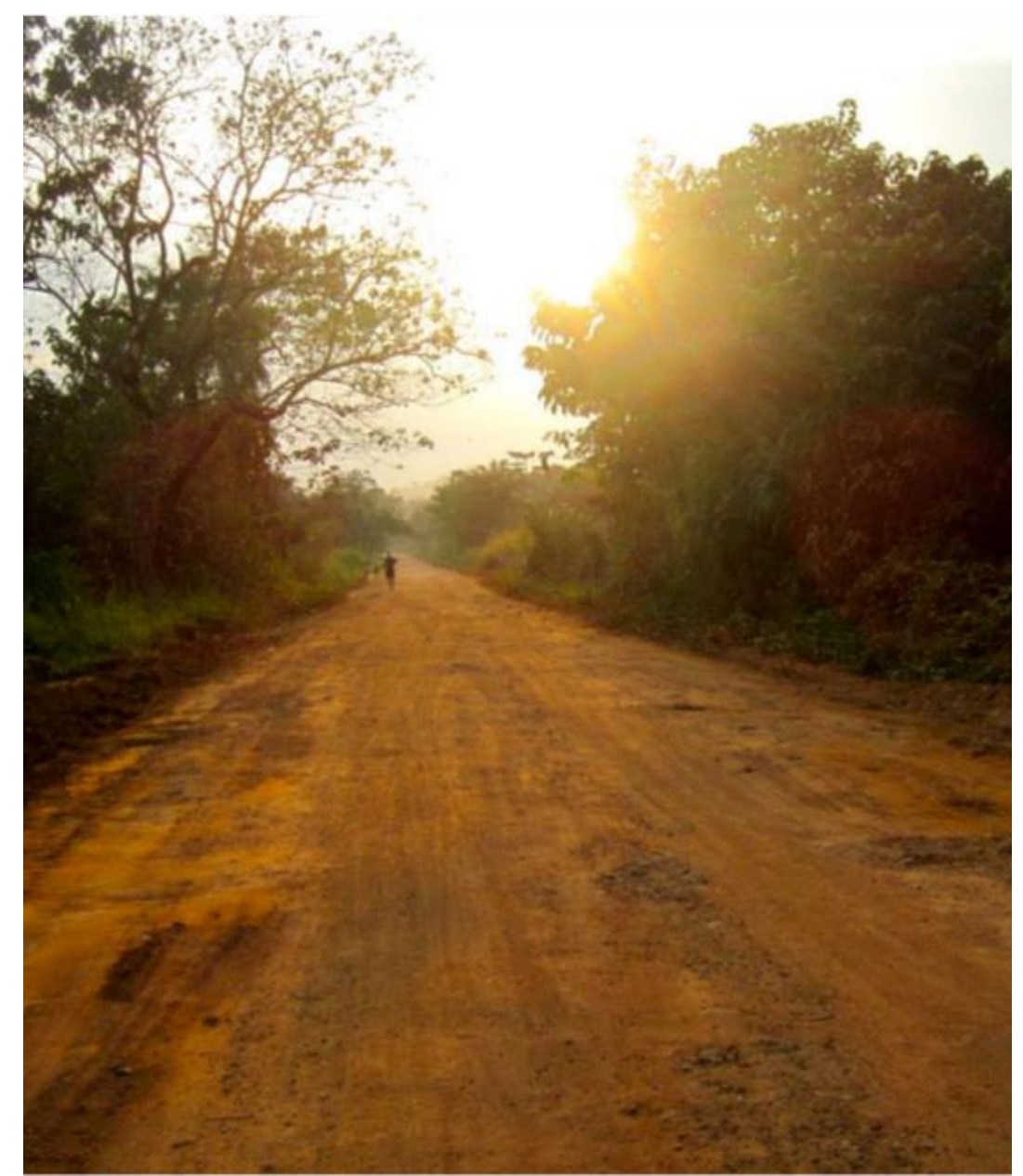




\section{Risks and remaining questions}

$\square$ Accountability and transparency

$\square$ Effectiveness

$\square$ Capture by local elites

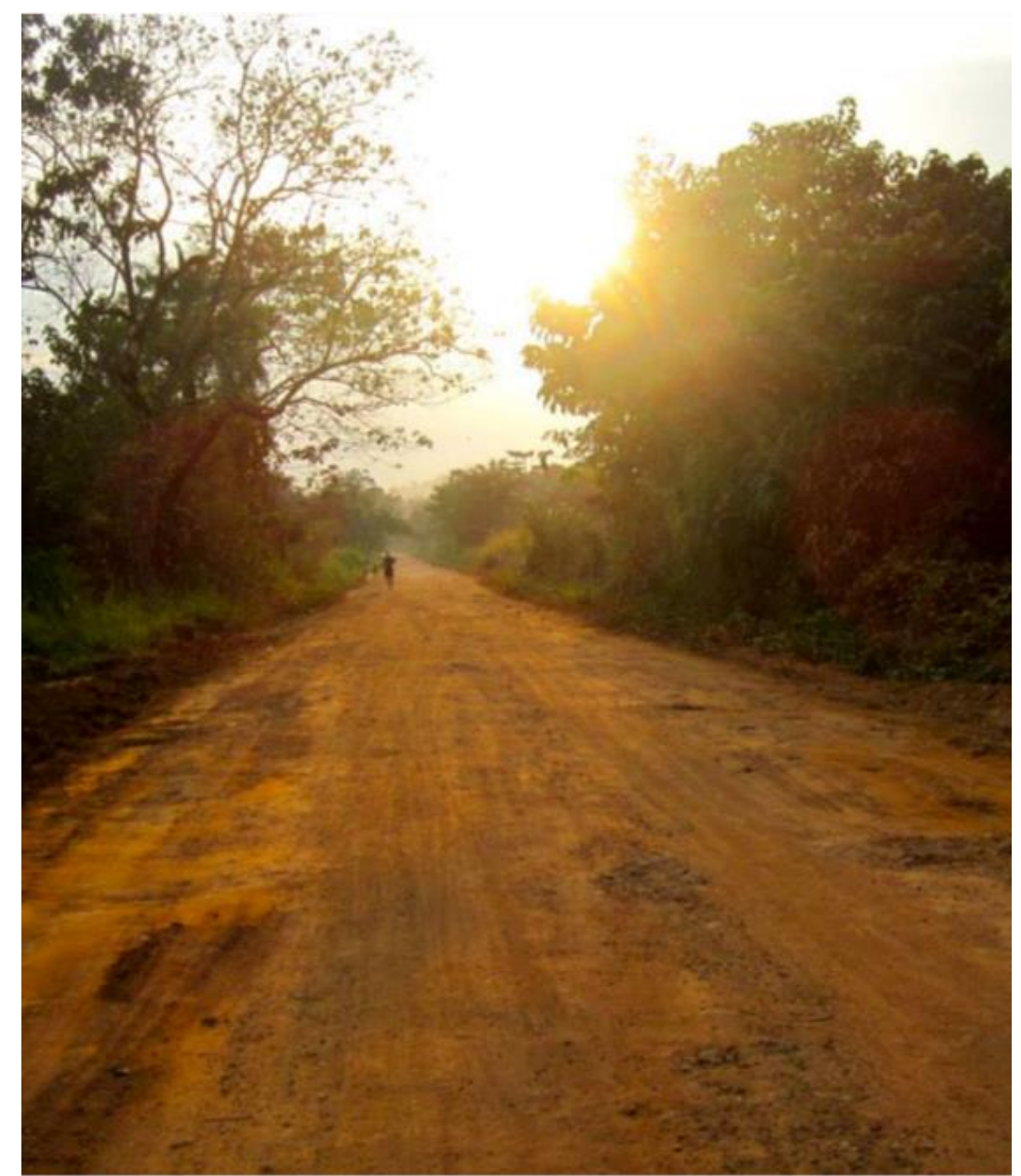




\section{Risks and remaining questions}

$\square$ Accountability and transparency

$\square$ Effectiveness

$\square$ Capture by local elites

$\square$ Impacts on long-term sustainability

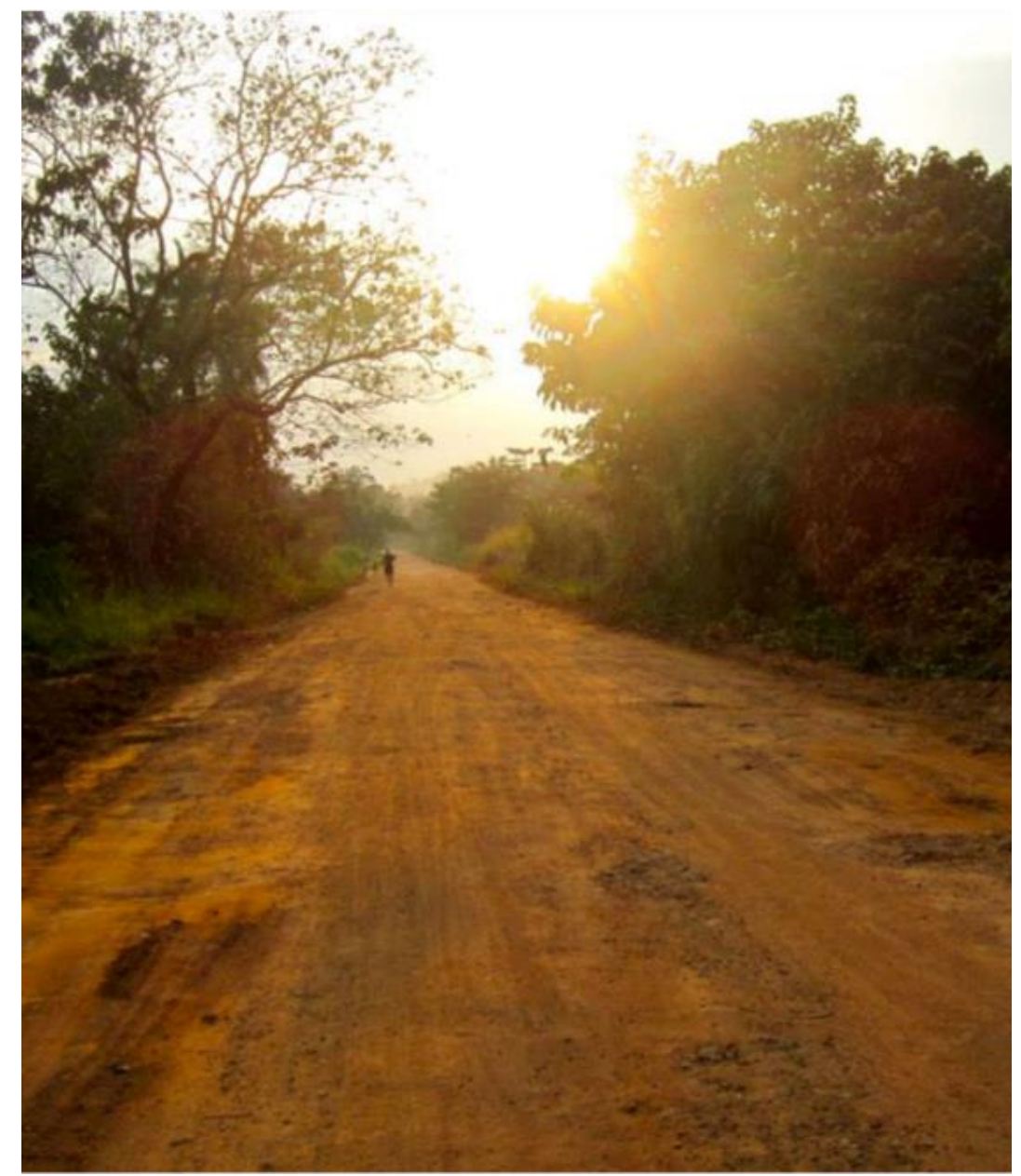




\section{THANK YOU}

Vanessa van den Boogaard

v.vandenboogaard@utoronto.ca 